\title{
AZ INTERPRETATÍV FENOMENOLÓGIAI ANALÍZIS (IPA) MINT KVALITATÍV PSZICHOLÓGIAI ESZKÖZ BEMUTATÁSA
}

\author{
SZAKIRODALMI ÖSSZEFOGLALÁS
}

\author{
RÁCZ JÓZSEF ${ }^{1,2}$, KASSAI SZILVIA $^{1,3}$, PINTÉR JUDIT NÓRA ${ }^{4}$ \\ ${ }^{1}$ Eötvös Loránd Tudományegyetem, Pedagógiai és Pszichológiai Kar, Pszichológiai Intézet, \\ Tanácsadás Pszichológiája Tanszék \\ ${ }^{2}$ Semmelweis Egyetem, Egészségtudományi Kar, Addiktológiai Tanszék \\ ${ }^{3}$ Eötvös Loránd Tudományegyetem, Pedagógiai és Pszichológiai Kar, \\ Pszichológiai Doktori Iskola \\ ${ }^{4}$ Szegedi Tudományegyetem, BTK, Pszichológia Intézet, Személyiség- Klinikai- és \\ Egészségpszichológia Tanszék \\ E-mail: racz.jozsef@ppk.elte.hu
}

Beérkezett: 2015. február 23. - Elfogadva: 2015.augusztus 25.

\begin{abstract}
Szakirodalmi összefoglaló tanulmányunkban az interpretatív fenomenológiai analizist (IPA) mutatjuk be. A módszert elsôsorban kvalitatí pszichológiai kutatásokban alkalmazzák. A tanulmányban összefoglaljuk az IPA fenomenológiai és hermeneutikai alapjait. Kiemeljük az IPA idiográfiai alkalmazását, ami egyben a módszer erôssége: részletgazdag bemutatást tesz lehetôvé, kis létszámú, homogén vizsgálati személyek esetén. Ismertetjük azokat a különbségeket, amelyek más fenomenológiai módszerektól megkülönböztetik az IPA-t. Bemutatjuk az IPA alkalmazását: a kutatói kérdés, a mintaválasztás, az interjúkészités és az interjúátiratok fenomenológiai interpretációjának lépései segitségével. Kitérünk a validitás kérdésére és ismertetjük a módszer gyakorlati korlátait (kis minta) és episztemológiai kockázatait (az interpretációnak nincsenek objektíven ellenôrizhetố kritériumai). Végül, néhány IPA-kutatást mutatunk be, ezekkel érzékeltetve a módszer kvalitatív pszichológiai használhatóságát: a krónikus betegség tapasztalatát, a pszichoaktív anyaghasználatot, a függóséget és a felépülést. Az IPA középponti témája az énhez, illetve az identitáshoz való viszonyulás változása.
\end{abstract}

Kulcsszavak: interpretatív fenomenológiai analízis, kvalitatív pszichológiai kutatások, interjúelemzés, identitás 


\section{BEVEZETÉS}

Tanulmányunkban az interpretatív fenomenológiai analízist (IPA) mint egy kvalitatív pszichológiai módszert mutatjuk be. Tudomásunk szerint ez az elsố hazai módszerbemutatás, noha az elsô IPA-t alkalmazó közlemény 1996-ban jelent meg (Smith, 1996). Az IPA eltér a más típusú fenomenológiai pszichológiai módszerektôl, tanulmányunkban ezt a kérdést is érintjük. Az utóbbi években a kvalitatív pszichológiai módszerek elterjedtsége és a kutatások száma egyaránt nôtt (Willig és Stainton-Rogers, 2013), az IPA-t is egyre gyakrabban használják a kvalitatív pszichológiai kutatásokban (Smith, 2011). A bemutatás során ismertetjük a módszer filozófiai alapjait, az alkalmazás lehetôségeit és a módszer előnyeit és korlátait. Utalunk a módszerrel szerzett tapasztalatainkra is (Kassai, Pintér és Rácz, 2015, Rácz és mtsai, 2015).

\section{Fenomenológiai háttér}

A fenomenológia, a 20. század egyik legnagyobb hatású filozófiai mozgalma nem kizárólag egy a filozófiai rendszerek között, hanem magának a gondolkodásnak a sajátos módszere (Ullmann és Olay, 2011). A fenomenológia a tapasztalat tudománya, érdeklôdésének fókuszában az áll, hogy közvetlen átélésben hogyan adódnak az ember számára a tapasztalatai, hogyan észleli a világot: a tárgyakat és önmagát, hogyan emlékezik a múltjára, hogyan éli meg saját érzelmeit, személyes azonosságát. Az iskola megalkotója Edmund Husserl (1859-1935) sokáig leíró pszichológiának nevezte a módszert, majd fenomenológiának keresztelte. Az elnevezés arra utal, hogy a mozgalom az egyes szám elsố személyú tapasztalat számára megjelenô fenoméneket, azaz a megjelenôt állítja vizsgálódása középpontjába (Husserl, 1905/2002). A fenomén fogalma azért lényeges, mert a különbséget jelöli a tárgy fogalmától, amely eleve feltételez egy külsô, objektív nézôpontot, amelybôl vizsgálhatjuk azt. A módszert fémjelzô felszólítás („vissza a dolgokhoz”) éppen arra utal, hogy a fenomenológia túllép a megismerés külsô-belsố hagyományos különbségtevésén, és abból indul ki, hogy az emberi tudat és tárgya „össze van kötve” egymással: tehát a dolgok nem önmagukban azok, amik, hanem jelentésük, értelmük abban áll, ahogyan számomra, a tudatom számára megjelennek.

\section{Intencionalitás}

A fenomenológia tehát annak megragadására törekszik, hogy közvetlen átélésben hogyan adódnak a dolgok az észlelố számára. Központi fogalma az intencionalitás, azaz a valamire való irányultság, amelyet Franz Brentano (1838-1917) dolgozott ki. A fogalom eredetileg a skolasztikából származik, Brentano azonban abban az értelemben használta, hogy a pszichikai fenomének mindig vonatkoznak valamire, és ezt a tudat lényegi jellemzójének tartotta. Husserl Brentanótól vette át a fogalmat, és a reprezentáció hagyományos fogalma helyett vezette be fenomenológiájában. Az intencionaliás közvetlen viszonyt tételez tudat és tárgy között, nem leképezés tehát, hanem értelemadás. Az intencionalitás fogalma arra vonatkozik, hogy a tudat mindig irányul valami- 
lyen dologra, tehát a tudat mindig csak mint valaminek a tudata gondolható el: a látás valaminek a látása, az emlékezés valamire való emlékezés, a vágy valamire való vágy. Ez ugyanakkor azt is jelenti, hogy tudatról sincs értelme önmagában beszélni, mert azt mindig betölti valami, amire éppen irányul, ami egyszersmind fel is építi.

\section{Redukció}

Az irányzat legfontosabb módszere a fenomenológiai redukció, amely az epokhéban, azaz az elôzetes meggyôzôdések és ítélkezések felfüggesztésében, zárójelezésében gyökerezik. Ez egyaránt vonatkozik a hétköznapi, kulturális és tudományos előfeltevéseinkre, továbbá arra, hogy a dolog, ami megjelenik számunkra, egyáltalán létezik-e. A természetes beállitódástól, azaz, amikor nem kérdôjelezzük meg meggyózôdéseinket, a fenomenológiai beállítódásig kell eljutnunk, tehát a számomra megjelenô dolgokat meg kell szabadítani a rájuk rakódott elôzzetes értelmezési rétegektôl. Ily módon válik a szemléló képessé a dolgokhoz való viszonyát neutralizálni, semlegesíteni. A fenomenológia arra képes ily módon rákérdezni, hogy az én miként konstituálja, azaz hozza létre, látja el értelemmel a tapasztalatait, világa egészét (Husserl, 1911/1972).

\section{3. Életvilág}

Az ént kizárólag a környezetével kölcsönhatásban lehet megérteni, amely azonban nem csupán a többi embert, de magát az életvilág egészét is jelenti. Az életvilág a fenomenológia értelmében az élet alapvetô közege, életünknek az a természetes horizontja, amelyhez lényegileg érzéki módon viszonyulunk (Husserl, 1936/1998). Továbbá a minket körülvevô, a múlttal állandó összeköttetésben lévô, történeti, kulturális és interszubjektív világ is egyben. A fogalom Husserlnek abból az elgondolásából ered, hogy a tudomány teoretikus beállítódása nem az egyetlen lehetséges hozzáférési út a valósághoz (Ullmann és Olay, 2011, 39).

Fontos látni, hogy a fenomenológiai iskola nem egy egységes vagy dogmatikus irányzat, egysége sokkal inkább sajátos módszerének és gondolkodási stílusának egységességében áll (Ullmann és Olay, 2011, 16). Az irányzat késôbbi képviselôi is jelentôsen továbbgondolták a husserli tanokat. Kutatásaikban vagy megmaradtak a tágan vett fenomenológiai iskola keretein belül (mint Maurice Merleau-Ponty, Jean-Luc Marion vagy Marc Richir), vagy munkásságuk nyomán olyan, egymással szorosan öszszefüggó iskolák jöttek létre, mint a hermeneutika és az egzisztencializmus. Maurice Merleau-Ponty, a francia fenomenológia legfontosabb képviselôje két fô múvében, Az észlelés fenomenológiája és A látható és a láthatatlan lapjain az emberi tapasztalat testi jellegét állítja vizsgálódása középpontjába. A kortárs pszichológiai és fiziológiai kutatások eredményeit is felhasználva észlelés- és tapasztalatelméletében kimutatta, hogy az észlelés és az értelmezés egymástól nem elválasztható. Merleau-Ponty az emberi tapasztalat nem intencionális, nem tudatos, „vad” rétegét helyezte kutatása fókuszába, ami minden észlelés alapja és háttere (Merleau-Ponty, 1945/2014). Ez az ún. prereflexív szféra, amely által, illetve a testiségünk által mintegy bele vagyunk kötve a fizikai világba (Merleau-Ponty, 1964/2007). Sartre-hoz hasonlóan ó is amellett érvel, hogy nincsenek készen adott jelenségek, az eredendô észlelés szintjén a világ mindig befejezetlen 
és sohasem teljesen meghatározott. Az észlelés tehát maga is alakítja a világot (Ullmann és Olay, 2011), ember és világ viszonyára egy egymásra oda-vissza ható kölcsönkapcsolat jellemző (Merleau-Ponty, 1964/2007; 1998).

\section{Hermeneutika}

A hermeneutika görög eredetú szó, az értelmezés tudományát jelenti. Az elsố hermeneutikai mú Arisztotelész nevéhez fúzôdik (Arisztotelész: Hermeneutika), késóbb a Biblia szövegeinek értelmezéséhez kötôdô módszertan, majd a 19. században Friedrich Schleiermacher, Wilhelm Dilthey és Hans-Georg Gadamer nyomán kialakul a filozófia hermeneutikai irányzata, amely a hermeneutikai nézôpont egyetemességét hirdeti mind a humán tudományok, mind az emberi lét lényegére vonatkozóan, „a megértés [...] magának az emberi létnek a létmódja”, fogalmaz Martin Heidegger nyomán Gadamer (1960/2003, 13-14).

Gadamer kiindulópontja, hogy bizonyos tapasztalatokhoz alapvetôen nem standardizálható eljárásokkal lehet hozzáférni. A filozófus nevéhez füzôdik a hermeneutikai kör koncepciójának kidolgozott változata (Gadamer, 1960/2003), amelynek alaptétele, hogy a szöveg egésze csak a részei révén ragadható meg, viszont az egyes részek értelme attól az egésztôl függ, amelybe azok bele vannak ágyazva. Az értelmezés folyamata így egy sajátos körmozgással írható le: az újabb információk, feltárult értelem összefüggések alapján az elôzô belátásaink is új értelmet nyernek. Az értelmezés ugyanakkor Gadamer szerint mindig magában foglalja nem tudatos hozzáállásunk, tradíciónk, elôzetes meggyôzôdéseink vállalását is. Ezeket ugyanakkor meg kell ismernünk, „tudatában kell lennünk a saját elôítéletinknek, hogy a szöveg megmutatkozzék a maga másságában” (Gadamer, 1960/2003, 303.).

A megértés akkor valósul meg, ha az értelmezó és az értelmezett horizontja összeolvad, azaz az értelmezô a saját kulturális, tudományos, személyes hátterét felismerve képes belépni a vizsgált tárgy világába, így feltárni annak értelem-összefüggéseit, hagyni, hogy annak „igazságigénye érvényre jusson” (Gadamer, 1960/2003). A megértés tehát egy érzékeny és dinamikus folyamatként írható le: olyan én-te párbeszédként, amely mindig a nyelv közegében zajlik, ez a szemléleti kiindulópont az IPA módszertana számára is lényegi fontosságú, ahogyan azt majd lentebb látni fogjuk. A „beszélgetôknek” egy közös nyelvet kell tehát találni, amelyen megértik egymást. A nyelvhasználatnak magának Gadamernél így mindig beszélgetéskaraktere van.

Paul Ricoeur, a hermeneutikai hagyomány másik meghatározó, francia képviselőjének nevéhez számos, a pszichológia számára is jelentôs belátást hozó elmélet kötôdik. Ilyen például a metaforikus igazság fogalma, amely arra vonatkozik, hogy a metaforákkal nem csupán új módon írjuk le a világot, hanem új világtapasztalatra is szert teszünk általuk (Ullmann és Olay, 2011, 249). Másik lényeges koncepciója a narratív identitás (Ricoeur, 1990), amely a személyes identitást érintố több problémára plauzibilis megoldást nyújt. Az én azonosságát abban a történetben, narratívában horgonyozza le, amelyet az elbeszél magáról, ezzel garantálva, hogy az én az élettörténete folytonos változása közepette is ugyanaz (az én) maradjon. 


\section{Egzisztencializmus}

Az egzisztencializmus az ember létének, egzisztenciájának mibenlétével, lényegi kérdéseivel foglalkozik: hogyan ismeri meg és értelmezi az ember a világát, hogyan „találja magát a világban" (Fehér, 2007, 29), mit jelent az autentikus vagy inautentikus létezés (Heidegger, 1927/2007). Az irányzat fố képviselője Martin Heidegger, aki 1919-tôl négy éven át Husserl asszisztense volt. Munkássága a fenomenológia és a hermeneutika irányzatához is szorosan kötődik. Az egzisztencializmus filozófiai irányzatának létrejöttét Heidegger fố múve, a Lét és idô megjelenéséhez kötjük. A filozófus szerint ahhoz, hogy egyáltalán feltehessünk a létre vonatkozó kérdéseket, a létezô létének, létmódjának kidolgozásából kell kiindulnunk (Heidegger, 1927/2007), ezt a diszciplínát jelöli Heidegger egzisztenciális analitikaként, amelynek módszertana a fenomenológia. Heideggernél a fenomenológia pedig hermeneutikai jelleget ölt, amennyiben a Dasein, azaz ittlét hermeneutikájából indul ki (Fehér, 2007). Heidegger Dasein-nak, azaz jelenvaló-létnek, ittlétnek, világban-való-lét (In-der-Welt-sein) hívja a szubjektumot, amivel arra utal, hogy az ember már mindig is bele van kötve a világba, léte világban-benne-lét (Heidegger, 1927/2007), tehát nem érthetô meg önmagában, hanem kizárólag a világgal való viszonyában, amit a Dasein folyton értelmez.

\section{Szimbolikus interakcionizmus}

Az IPA előzményei sorában hasznos röviden megemlíteni egy, a szociológiai, szociálpszichológiai hagyományban gyökerező elméleti keretet, a szimbolikus interakcionizmus elméletét, amely arra kínál modellt, hogyan konstruálják a jelentést az emberek a személyes és szociális környezetükben (Smith és Osborn, 2007). Az elmélet alapgondolata Georg Herbert Mead nevéhez kötődik, akinek kiindulópontja, hogy a környezethez való alkalmazkodás, világ és önmagunk megértése, az identitástudat a szimbólumok alkalmazásának a képességében áll. Az emberi viselkedés, értelmezés lényegileg szimbolikusan közvetített, és a nyelvi kommunikáció által irányított (Mead, 1934). Később Herbert Blumer volt az, aki megfogalmazta a „szimbolikus interakció” gondolatát (Blumer, 2000), arra helyezve a hangsúlyt, hogy a szimbólumok folytonos interakcióban vannak egymással.

\section{Fenomenológiai pszichológiai kvalitatív kutatási megközelitések}

Az interpretív fenomenológiai (IP) módszer teoretikusan elsôsorban Heidegger és Gadamer munkásságán nyugszik, és az egyik fố megalapozója Amedeo Giorgi volt (Langdridge, 2007; Wertz, Charmaz, McMullen, Josselson, Anderson és McSpadden, 2011). Az IP a hermeneutikai kör tanulmányozásával foglalkozik, elsôsorban az „elôzetes tudások" megismerésével, és ezek felismerésével. Egyes szerzôk tagadják, hogy ennek a módszernek egy jól leírható metodikája lenne, míg mások feltételeznek ilyet (Giorgi és Giorgi, 2008). Utóbbiak közé tartozik - egészségpszichológiai vonatkozásban - Patricia Benner (Benner, 1984; 1994). Bennert ápolóként az ápolási tapasztalat 
és az ápolási szakmai karrier érdekelte. Benner és Chan (2010) az IP-t a racionális-empirikus kutatásokkal összehasonlítva, annak az életvilággal kialakított közvetlen kapcsolatát hangsúlyozza: a tapasztalat mindig kontextusfüggő, és az életvilágban, illetve az emberek tapasztalati világában helyezkedik el. A patologikusat diagnosztizáló vagy a megküzdési hiányosságokat megállapító „klinikai modell” kizárja az életvilágot. Az IP a normális, egészséges megküzdés különbözô változataira vagy éppen ezek hiányára fókuszál. Azonban nem lehet a megküzdés nehézségeivel foglalkozni addig, amíg magát a megküzdést nem értjük meg, annak szituációfüggó vagy éppen interperszonális vonatkozásaival együtt. A normalizáló diskurzus - és itt a szerzôk Foucault nézeteire hivatkoznak (magyarul: Foucault, 2000) - ugyanis nem teszi lehetôvé a betegség megtapasztalásának bemutatását. Benner és Chan (2010) szerint ugyanakkor az ápolók könnyen megérthetik a betegség tapasztalatát, amelyet az olyan emberek „gondjai” (concerns ${ }^{1}$ ) és megküzdési képességei alakítanak ki, akik fogyatékkal, akut vagy krónikus betegséggel, vagy sérüléssel élnek egy adott életvilágban.

Kesselring, Chesla és Leonard (2010) IP-kutatásaiban az interjúkra építenek. Az interjúkkal kapcsolatos módszertani fejtegetéseikból azt érdemes kiemelni, hogy ezek az interjúk miért és mitôl mások, mint egy empátiára és nyitottságra építô interjú. Hogyan kell olyan interjút készíteni, ami lehetôvé teszi az IP-t? Látni fogjuk, hogy az interjúkészítés és az elemzés szorosan összekapcsolódik. Ha van egy interjúszövegünk (amit empatikus légkörben, lehetôleg nondirektív módon készítettünk), az még önmagában nem elegendô ahhoz, hogy IP-t végezzünk el „rajta” (mint egy tárgyon).

Az IP az interjú módszerét úgy tekinti, mint olyan lehetôséget, ami a kutató és az interjúalany számára megteremti a „feltárulkozás terének” (disclosive space ${ }^{2}$ ) kialakulását, ahol a kutató olyan pozícióba kerül, amelyból megértheti az interjúalanyt. Ahogy a mindennapi életben, úgy az interjúban is, a résztvevôk feladata egy feltárulkozó közös világ megalkotása, amely a jelentések gazdag lehetôségét tartalmazza. Az interjúban az elbeszélt történethez úgy viszonyulunk, mint ami a mindennapi élet szokásaira támaszkodik. Nem az ilyen szokások reflexióin, ezek oksági kapcsolatain vagy eredményein alapulnak, vagy azon, hogy valamilyen mély megértésig „ásunk le”. A kutató „bele van vetve" az interjúalannyal való találkozásba. Arra szólítja fel az interjúalanyt, hogy az ôt foglalkoztató témákról (concern) beszéljen, miközben ô nyitottan, kíváncsian figyeli, és az interjú elôrehaladottabb fázisában - amikor már a kapcsolat kialakult - néhány témát maga is felvet.

Kesselring, Chesla és Leonard (2010) néhány témakört is megemlít, amire az interjúban kitérhetünk: pl. mi foglalkoztatja az interjúalanyt itt és most?; miért mondja el a történetét és miért éppen most?; hogyan kapcsolódik ez a történet az interjú egészéhez, vagy miért válik el attól?; ki vagy kik a történet szereplöi?; hogyan jelennek meg a szereplő́k a történetben?; milyen tágabb kontextusban helyezhetô el a történet?

\footnotetext{
${ }^{1}$ A „concern” magyarul - a heideggeri terminológia értelmében - leginkább vonatkozásként lehet fordítani, esetleg törôdésként. Ebben a szövegkörnyezetben az „aggodalom” vagy az „ami foglalkoztatja az embert” kifejezéseket használjuk.

2 A „disclosure” a heideggeri kontextusban feltárulkozást jelent. A „disclosive space”-re a feltárulkozás tere vagy feltárulkozási tér kifejezéseket használjuk.
} 
Megjegyzik ugyanakkor, hogy fontos ezekról a témákról beszélni, de a témakörök kijelölése kockázatot is magában rejt: a saját megértési folyamatunk elnyomhatja az interjúalanyok feltáró munkáját.

Az interjúalanyt foglalkoztató dolgok (concerns) interpretációja az egész interjú figyelembevételével történik, így megállapíthatjuk, mik azok az általános erôk, amelyek az interjúalany gyakorlatait, világban levô létét irányítják. Ahogy az interjú során egyre jobban megértjük az interjúalany történeteit és azt, mi foglalkoztatja (concern), illetve ahogy az interjúalany visszatekint korábbi tapasztalataira, egyfelól elôsegíti mindkét résztvevố számára, hogy lássák azokat a transzformatív gyakorlatokat, amelyekkel az interjúalany létrehozza történeteit. Másfelól lehetôvé válik az interjúkészítô számára a folyamat megértése is.

Az IP által facilitált megértő-önfeltáró munkára McNiesh (2010) kutatásait említjük meg, aki azt vizsgálta, hogyan lesz valaki ápoló: hogyan lesz egy laikusból a tanulmányai végére egy olyan személy, aki ápolóként „létezik”, „van” (being). A kutatások közül is kiemelünk egyet, ami a tanuló ápolók szüléssel kapcsolatos elsố tapasztalatait vizsgálta.

Az ápolóvá válás folyamata identitás-transzformációt jelent, miközben gyakorlati készségeket és tudást sajátít el. A folyamat a szokások mindennapi világához történô elkötelezôdésben és az ápolásban részt vevô családokkal és páciensekkel való találkozásokban valósul meg. A szülés egy olyan kitüntetett alkalom, ahol az ápolók a Másikkal találkozhatnak a szülés „gyakorlása” során. A szerzôk példájában, az ápolók egyes szám, elsô személyú beszámolóikban elmondták az adott szülés során szerzett furcsa tapasztalatukat, ami az újszülött szokatlan elnevezéséhez kapcsolódott (Bentazume lett az újszülött neve). Azonban ez a tapasztalat irányította rá a figyelmüket a névadás jelenségére és az új „létezôvel” kialakítandó kapcsolatra. A pácienssel és a családjával való együtt-lét (Being-With) kiterjesztette az ápolók megértési horizontját az elsố pillantásra furcsának tûnô szokásokkal összefüggésben is. A különbözô kultúrák bármennyire is különbözzenek, a gondozás fenoménjában minden létezô osztozik. A gondolatmenetet folytatva, az ápolók egy technológiai világba „vetettek”, ahol meg kell tanulniuk a szülés mint az ember fejlôdésének egyik szakaszát és az ahhoz kapcsolódó szokásokat felismerni és megérteni. Ehhez elôször is meg kell érteniük a saját élményfolyamatunk alapján, hogy mit is jelent az értelemteli világba vetettségük. Elsô kézból kell megragadniuk azt a tapasztalatot, amit a kultúrában a szülés jelent, mint egyfajta eljövetelt, egy új élet kezdetét. Tapasztalati tanulás útján kell ennek az emberi életútszakasznak a jelentôségét megérteniük és felfogni azt, hogy ennek technikai kivitelezését miért övezi annyi aggodalom (concern). Az újszülött ugyanis egy medikalizált kórházi környezetben jelenik meg, ahol az ápolást háttérbe szorítja a technológia. Ugyanakkor a technológia a megértés új lehetôségeit is megteremti: tudhatjuk a magzat nemét, súlyát már a terhesség alatt is; a szülést az apa egy mobil eszközzel közvetítheti a családtagoknak, stb. Így az ápolóknak a szülés technológiai és gyakorlati aspektusait mint a két világ megértéshorizontjának összeolvadását kell megérteniük, ami új lehetôségeket teremt a szülés élményének feltárulkozására.

Az IP a fenomenológia elmélyültebb ismeretét feltételezi, és az értelmezésekben is megjelennek a fenomenológia kulcskifejezései (pl. Crowther, Smythe és Spence, 
2014). Az IPA ezzel szemben a fenomenológiára építve egy olyan elemzési rendszert hozott létre, hogy annak követésével a módszer kivitelezhetô akkor is, ha a kutató a filozófiai háttér mélyebb ismeretével nem rendelkezik.

\section{Az IPA helye a kvalitatív pszichológiai kutatások között}

A kvalitatív pszichológiai kutatásokkal foglalkozó SAGE kézikönyv 13 módszert sorol fel, amik közül az egyik az IPA (Willig és Stainton-Rogers, 2013). Az IPA-t bemutató fejezet (Eatough és Smith, 2008) a kvalitatív kutatási irányzatok közül elsósorban a szociális konstruktivizmus, a diszkurzív pszichológia, valamint a narratív pszichológia keretében igyekszik elhelyezni a módszert. A szerzók szerint az IPA szociális konstrukcionalista vonásai inkább a szimbolikus interakcionalizmushoz állnak közelebb, mint a diszkurzív pszichológia nyelvi és diszkurzív konstrukcióihoz. Az IPA szerint ugyanis az életvilág jóval több, mint az emberek között, történetileg helyzethez kötött módon zajló nyelvi interakciók. Ha az emberek történeteket mesélnek az életükrôl, akkor nem pusztán a kulturálisan hozzáférhetô jelentésraktáraikból válogatnak, hanem történetmondással bizonyos célokat kívánnak elérni: rábeszélni vagy racionalizálni, megốrizni a tekintélyüket; azaz a specifikus helyi interakciónál többre törekednek. A szerzők szerint a személyes beszámolók az emberi lehetôségeket és a fejlôdést is tartalmazzák azzal, hogy mi „csináljuk” az életünket a múlt, a jelen és a jövő összekapcsolásával, egy imaginatív vállalkozás keretében. Az IPA a foucault-i diskurzus-analízishez is kapcsolható. Eatough és Smith (2008) az érzelmek „tartály”-elméletét idézik: az érzelmek a tartályból kiömölhetnek vagy emelhetik a tartályban levő folyadék szintjét. Ha a haragunk például kontrollálatlanná válik, akkor olyan metaforákat használunk, amelyek magunkat passzív ágensként tünteti fel, aki (vagy ami) elszenvedi a haragot. Az IPA ebben az esetben azt vizsgálja, hogy ez a „tartály”-konstrukció - pl. a harag élményének elbeszélése során - miként konstruálódott, és az egyes személyek miként tapasztalják meg.

Eatough és Smith (2008) az IPA-t a narratív pszichológiával is összehasonlítják. A narratíva is interpretáció, amit az egyes emberek nemcsak megkonstruálnak, hanem azzal magát a valóságot is létrehozzák. Tehát az emberek nem pusztán történetek elbeszélôi, hanem a történetek a világ megtapasztalásának eszközei is. Az IPA különösen az újra-elbeszélt történetek iránt érdeklôdik, pl. amikor valaki a tanácsadás vagy a terápia folyamán újra-interpretálja, majd újra-elbeszéli életének fontos epizódjait. Így a megélt tapasztalat újra-értelmezésével az élete élhetôbbé válik.

A korábban emlegetett kvalitatív pszichológiai módszerek között csak felsorolásszerúen említjük az etnográfiát, az akciókutatást, a párbeszédelemzést, a diszkurzív pszichológiát, a foucault-i diskurzus-elemzést és a narratív pszichológiát (utóbbiakra részletesebben is kitértünk), a fenomenológiai pszichológiát (ezt is említettük), a szociális reprezentáció-elméletet, a Q módszertant és a „megalapozott elméletet”, a Grounded Theoryt (GT). A felsorolt módszerek közül most csak a GT-t emeljük ki (Charmaz, 2013; Charmaz és Henwood, 2008; Corbin és Strauss, 2015), elsôsorban azért, mert talán ez a legismertebb és legelterjedtebb módszer a hazai kvalitatív kutatásokban (Gelencsér, 2003; Mitev, 2012). A GT egyik megalapítója (Strauss) és továbbfejlesztôje (Corbin) a következóképpen foglalják össze a GT szemléletét: „Jóllehet na- 
gyon érdekel minket, hogy az emberek miként élik meg a velük történt eseményeket és milyen jelentésekkel ruházzák fel ôket, egyúttal azt is számításba kell vennünk, hogy az élmények magyarázata nem volna teljes két dolog nélkül. Az egyik, hogy a tapasztalatokat el kell helyeznünk abban a tágabb keretben vagy kontextusban, amelybe beágyazódnak. A másik pedig, hogy le kell írnunk a folyamatokat, továbbá az akciók, interakciók és érzelmek mindazon folyamatban levô és változó formáit, amelyek az események hatására létrejönnek - sốt mindazokat a problémákat, amelyek az akciókat és az interakciókat akadályozzák. Odafigyelünk a következményekre is, hiszen ezek a cselekvés egymást követô szegmenseiben vissza-visszatérnek (Corbin és Strauss, 2015, 55-56). A GT pszichológiai kutatásokban való megjelenése - elsôsorban a klinikai és egészségpszichológiai vizsgálatokban - együtt járt a módszer leegyszerûsödésével és „elöírásszerú” alkalmazásával, ennek pozitív oldalával (a módszer alkalmazási körének kiterjedése, gyakoribb használat) és negatív aspektusával (a kifinomult elemzés háttérbe szorulása, leegyszerúsödése) (Charmaz és Henwood, 2008).

A GT során az adatokból fogalmakat hozunk létre, majd ezekbool „elméletet”. Az IPA-nál törekszünk az adatok (tapasztalatok, élmények) szintjén maradni; nem általánosítunk és absztrahálunk, nem alkotunk elméletet. A GT a szereplők közötti cselekvések és interakciók mintázataira, illetve a közöttük végbemenô folyamatokra kíváncsi: mi történik a cselekvôkkel, a mintázatokkal bizonyos körülmények között. Az IPA a mintázatok ilyen értelmezése helyett inkább idiográfiás módszer: a cselekvók tapasztalatait és élményeit igyekszik feltárni és megérteni. Közvetlenül az adatokból dolgozik, azokat nem vonja fogalmi egységek alá, mint azt a GT elemzési részében tesszük.

\section{AZ IPA}

\section{Az IPA módszertana}

Az IPA tehát interpretatív, hermeneutikai módszer, amely sajátosság több szinten is megnyilvánul a kutatás során. Smith, Flowers és Larkin (2009) egy korábbi kutatásból (Osborn és Smith, 1998) hozott példája igyekszik ezt megvilágítani egy olyan nôi interjúalany (Linda) példáján, aki krónikus hátfájdalommal él. Az értelmezés elsô szintje a társas összehasonlításokra vonatkozott, nevezetesen arra, hogy a nô hogyan „veszítette el énjeit”, azaz múltbeli énjét, továbbá azt az ént, amivé válhatott volna, és azokat az éneket, amikkel találkozott életútja során. Az interpretáció második szintjén azt vizsgálták, hogy az interjúalany milyen metaforákkal írja le a veszteségeit, összehasonlítva magát másokkal. A harmadik szint az interjúalany beszámolóinak idôbeli konstrukciója volt: hogyan írta le magát jelen és múlt idôben. Az idôbeli változások a „valódi szelfért” folytatott küzdelemre utalnak, ami az interjúalanyt lekötötte. Mindegyik interpretáció egyre kifejezettebb volt, azonban ezek a szöveg olvasatán alapultak. Ezt összevethetjük a „külsô” szempontból történô interpretációval, például a pszichoanalitikus megértéssel - mely lehetôséget ad, az elemzés egy további, negyedik szintjéhez -, amikor a szövegen kívüli terminust használunk az értelmezéshez (mint például a késôbb tárgyalt fallikus szimbólum esetében), ez azonban már nem jellemzô az IPA szöveghú elemzésére. 


\section{Az IPA-kutatás menete}

\section{A kutatói kérdés}

A kutatási kérdés megfogalmazásakor tudatában kell lennünk annak, hogy az IPA-val azt áll módunkban kutatni, ahogyan az emberek megértik saját tapasztalataikat. Így a kutatási kérdés minden esetben nyitott (és nem lezárt), explorációs (és nem magyarázatot célzó), inkább a folyamatra (és nem a végeredményre) fókuszál, valamit a jelentést célozza (és nem az okokat vagy a következményeket). A kutatási kérdésünknek egy specifikus kontextusra kell vonatkoznia (a kontextusok közötti összehasonlítás helyett). Az elsố kutatási kérdést egy második szintú kutatási kérdés követi, ami pedig már lehet egy elméletileg megalapozott kérdés, és az értelmezés második szintjén válaszolható meg. Smith, Flowers és Larkin (2009) példája erre az elsô szintú kutatói kérdésre: „hogyan értelmezik az emberek az orvosi kezeléssel kapcsolatos döntéseiket?” A második szintû kutatói kérdés: a „döntési folyamatról szóló beszámolókat milyen mértékben lehet egy elmélettel magyarázni?”

\section{Mintaválasztás}

Az IPA esetén elméleti és célzott mintavétellel dolgozunk. A minta tagjai hozzáférést biztosítanak a vizsgálni kívánt különös jelenséghez, akik inkább egy „perspektívát” reprezentálnak, nem pedig egy populációt. Mivel az IPA idiografikus módszer, egy adott jelenséget meghatározott kontextusban vizsgál, ezért kis mintaszámmal dolgozik, aminek az is az oka, hogy a mintának minél homogénebbnek kell lennie az interpretálandó jelenség tekintetében. Smith, Flowers és Larkin (2009) példája nyomán a homogenitást úgy képzelhetjük el, hogy ha például depressziós betegek elsốterápiás tapasztalatára vagyunk kíváncsiak, akkor a minta legyen homogén abban az értelemben, hogy a vizsgálati személyek hasonló ideje szenvednek depresszióban, hasonló náluk a betegség súlyossága, hogy mennyi ideje voltak terápiában az interjú idôpontjában, és hogy korábban részesültek-e terápiában.

Smith, Flowers és Larkin (2009) saját tapasztalataik alapján 3-6 fôs mintát javasolnak. Ennyi még nem túl sok a részletes elemzéshez, viszont éppen alkalmas az egyes esetek közötti hasonlóságok és különbségek leírására. Tapasztalati alapon BA- vagy MA-szintû kutatásokra a háromfős, PhD-szintû kutatásokra pedig egy mintaválasztási sorozatot javasolnak: az elsố legyen egy esettanulmány, a második egy három fớbôl álló mintának a vizsgálata, majd a harmadik lépésben legyen ennél nagyobb elemszámú minta (például 8 eset). A szerzók szerint az egyesetes minták (azaz az esettanulmányok) általában nagyobb kvalitatív kutatói gyakorlatot igényelnek.

\section{Adatgyüjtés}

Az IPA céljaira legjobban a mély- és a félig strukturált interjú felel meg, mely akkor igazán eredményes, ha az interjúalany „sokat beszél”, és az interjúkészítô keveset. Ideális, ha az interjúban az egyes szakaszok között megjelennek narratív és leíró, valamint analitikus és értelmezô szakaszok. Mivel az interjúalany interpretációira vagyunk kí- 
váncsiak, az interjútervet nem kell mindenáron tartani: át kell engedni a vezetést az interjúalanynak. Továbbá el kell kerülnünk az interjú során az értelmezést, az összefüggések és a belátások keresését. Fontos, hogy rákérdezzünk, hogy a tanulmányozni kívánt jelenség - például egy betegség megélése - mit jelent az interjúalanynak; hogyan látja magát a betegsége alatt, a tünetek jelentkezésekor és tünetmentesen, illetve hogyan látta magát a betegség elôtt. Jó, ha az interjúalany egy-egy példát részletesen is elmond (Smith \& Osborn, 2007). Az interjúátirat elkészülte után - ha erre lehetôség van - célszerú egy tisztázó, második interjút is készíteni (Wagstaff és Williams, 2014).

\section{Az adatok elemzése}

Az átiratok többszöri elolvasása (ez az ún. „elmerülés az adatokban”: Smith és mtsai, 2009, 82) és a sorról sorra történô szabad tartalmi analízis során (Ryan és Bernard, 2000; Silverman, 2013) leíró, magyarázó, értelmezô és konceptuális jegyzeteket készítünk Smith, Flowers és Larkin (2009) javaslata szerint az átirat jobb oldali margóján. A fogalmi jegyzetelés már „elszakad” a közvetlen szövegtôl, és az interjúalany általánosabb szinten megjelenô megértéseit igyekszik megragadni. Ezt a fázist a gadameri dialógussal jellemezhetjük: az elôzetes tudásunk és a vizsgálati személyek tapasztalatainak folyamatosan kialakuló megértése között zajló „párbeszéddel”. A következô lépés a „kibontakozó témák” (emerging themes) megjelölése. A hermeneutikai ciklus segítségével érzékeltetve: az interjúk „értelmes egészét”, azaz a vizsgálati személyek narratíváit fel kell bontanuk egy más szempont szerint, mint az interjút generáló résztvevôi perspektíva. Most nagyobb hangsúly kerül a kutató, szervezó és értelmezô szerepére, aki a kibontakozó témák segítségével egy új „egészt” hoz létre. A kutató a résztvevook megélt tapasztalataival dolgozik és a létrejövô elemzés kettôjük közös erôfeszítésének eredménye. A témák meghatározásakor figyelnünk kell arra, hogy az interjú egyes pontjain mit mond az interjúalany, továbbá arra is, hogy az összes interjúban milyen magyarázatokkal találkoztunk. Már nem a résztvevôk kifejezéseit, szavajárását használjuk, hanem a kutatóét. Smith, Flowers és Larkin (2009) javaslata szerint a kibontakozó témákat az átiratok bal oldali margójára érdemes írni. A témák elnevezésekor, pontosabban az értelmezési folyamatban megjelenhet például az „elveszett szelf” kifejezés (például egy betegségtapasztalat során). Feltehetô, hogy ezt a kifejezést - és mindazt, amit a pszichológia számára a szelf jelent - az interjúalany nem használta. Itt tehát lehetôség van „pszichológiai” konstruktumok beemelésére az értelmezési folyamatba.

A következố lépésben az így kialakult témák között keresünk kapcsolatot: kronológiait, fölérendelt témákat (ami alá több téma tartozhat) - így absztraktabb témákat kapunk; polarizálhatjuk a témákat (például egy diagnózis hatására kialakuló, az én számára pozitív és negatív témákat), stb. Az egyes kibontakozó témákhoz az átiratokból idézeteket rendelhetünk, majd a témák közötti kapcsolatkeresés során a témákat és a hozzájuk tartozó idézeteket - külön-külön lapra felírva - mozgathatjuk. Ha egy esettel végeztünk, térhetünk rá a következó interjúra (kivéve, ha egyesetes esettanulmányt készítünk). Igyekszünk feltárni az egyes esetek között a témák, témacsoportok mintázatait. A „kibontakozó témákból” a további interpretációval kapott témákat nevezzük fơtémáknak (master themes). Célszerú ezeket a fốtémákat táblázatba foglalni, és az egyes fớtémák alá tartozó témák idézeteit is feltüntetni. 


\section{Adatok elemzése: az értelmezés bemutatása egy példán keresztül}

Smith, Flowers és Larkin (2009) az értelmezések fokozataira egy, a krónikus hátfájdalommal foglalkozó korábbi kutatásukat hozzák fel példának, abból is egy rövid szakaszt (Osborn és Smith, 1998, 70). Az interjúalany, Linda mondja:

„Azt hiszem, én vagyok a legfittebb, mert három lány van és én vagyok a középsô és azt hittem, én voltam a legfittebb, és úgy dolgoztam, mint egy ló, és azt hittem, hogy én vagyok a legerősebb, aztán, hirtelen, összetörtem (cut down), és fele annyit tudok megtenni, mint azelôtt tudtam."

Linda beszámolójának három szinten történô elemzése jól illusztrálja az IPA értelmezési folyamatát. Az értelmezés elsố szintjén Linda összehasonlítja magát a testvéreivel (társas összehasonlítás). A második szinten egy metaforát használva, lóhoz hasonlítja magát: ezzel erôteljesen kifejezi, mennyire erôs volt korábban és mennyire gyenge most. Az „összetörtem” is ezt az érzést fejezi ki. A harmadik értelmezési szinten az idôbeliségre figyelünk: Linda jelen idôben kezdi a mondatot, majd múlt idôre vált. Az „én vagyok a legfittebb” - „én voltam a legfittebb” egy identitásküzdelmet jelez, ahogy a hátfájás elpusztította a korábbi identitását. Linda elismeri, hogy elvesztette az identitását: az erôs, autonóm szelfjét, amit egy gyenge és vulnerábilis szelf váltott fel. Ugyanakkor Linda még azonosul a korábbi identitásával, az identitásának még része ez a szuper erôs létezés is. Az idôbeli váltás a régi és az új identitás közötti küzdelmet fejezi ki. Ez az értelmezés azonban csak úgy lehetséges, ha a pársoros idézetet Linda teljes interjújához képest értelmezzük: a rész és egész értelmezéssel.

Még egy negyedik szintú értelmezés is lehetséges: a ló Linda szexuális kívánságát és frusztrációját szimbolizálja. A szerzôk ezt a pszichodinamikus értelmezést - ugyan nem zárják ki a lehetôségek közül, de mivel más ismeretelméleti („külsôdleges”) perspektívából közelíti meg a jelenséget - nem tartják a („belsô” pozícióból értelmezô) IPA-ra jellemzőnek. Az IPA a Ricoeur-féle empátiás hermeneutikával a szöveg szoros olvasására biztat, így a „külsôdleges” szempont - a „gyanú hermeneutikája” pozícióból megfogalmazva - már kívül esik az IPA értelmezési körén. Ugyanakkor ez az értelmezés is lehetséges, amit úgy világítanak meg a szerzók, hogy a Ricoeur-féle hermeneutikák (az empátiás és a gyanú hermeneutikája) szerinti „köztes” pozícióról beszélnek. Feloldásként azt javasolják a szerzôk, hogy ha „külsô” szempontú értelmezéssel, azaz egy jól körülhatárolható elméleti pozícióból megfogalmazható értelmezéssel kívánunk élni, akkor azt válasszuk el a szöveg értelmezésétôl, és egy külön szakaszban tegyük meg.

\section{Validitás}

Az IPA validitásával kapcsolatos megfontolásokat Smith, Flowers és Larkin (2009) és Shinebourne (2011) ismertetik. Felhasználták ehhez Yardley (2000) tanulmányát, amelyben kvalitatív kutatások validitási problémáival foglalkozott. Az elsô kérdés az IPA-kontextus érzékenysége. Az IPA-kontextus érzékenységét mutatja a homogén mintaválasztás: egy adott kontextusban szereplő, más mutatókban is hasonlító vizsgálati személyek kiválasztása a kutatás számára. Egy-egy speciális kontextus (például hemo- 
dialízises betegek dialízise) vizsgálatát a kisszámú mintavétel is elôsegítheti (célzott mintavétel). Az IPA módszertanával végzett kutatást bemutató szövegnek (tanulmánynak, elemzésnek) olyan „erôsnek” kell lennie, hogy az alkalmazott magyarázatokkal és idézetekkel meg tudja jeleníteni a vizsgálati személyek tapasztalatait az olvasó számára. A kutató kontextussal kapcsolatos érzékenysége a hivatkozott irodalmon, valamint az irodalmi ismeretek és a saját kutatás közötti viszonyon keresztül is megmutatkozik.

Yardley (2000) második pontja a validitást illetô kérdések kapcsán az elkötelezôdés és a szigorú szabályosság. Smith, Flowers és Larkin (2009) szerint az elkötelezôdés megjelenik az interjúalany válaszkészségében, az interjúkérdések iránti figyelmében. A kutató részéról pedig abban, hogy a vizsgálati személy számára komfortos körülményeket és empatikus légkört hoz létre. Ezen túl a kutató folyamatosan fejleszti azokat a készségeit, amelyek a kvalitatív kutatáshoz szükségesek. A szigorú szabályosság pedig a kutatói kérdésnek megfelelô minta kiválasztásában, az interjúk minôségében és az elemzés egyes lépéseinek végigvitelében mutatkozik meg. A szisztematikus adatgyújtés és elemzés mellett meg kell maradnia az IPA idiografikus jellegének: ezt az idézetek használatával és a leírás részletességével érjük el.

Yardley (2000) következô pontja a transzparencia és a koherencia. Smith, Flowers és Larkin (2009) szerint ez a két jellemzó az IPA-ban a következóképpen mutatkozik meg. A kutatás egyes lépéseinek bemutatása a transzparenciához nélkülözhetetlen. Le kell írni a minta kiválasztásának szempontjait, az interjúzás körülményeit, az átiratok készítésének módját, valamint az elemzések folyamatát: az elsôdleges megjegyzéseket, a kibontakozó témákat, illetve az ezek összevonásával, egymással logikai kapcsolatba hozott (alá- és fölérendelô, csoportokba vont) témák kialakulását. A koherencia leginkább az olvasó meggyôződésében érhetô tetten, hogy megérti a kutatás folyamatát, követni tudja a kutató eljárását, tehát a leírásból semmilyen lényegi elem nem maradt ki. Az olvasónak meg kell értenie, hogy a vizsgálati személyek milyen tapasztalatokról számolnak be, hogyan értelmezik azokat, majd pedig meg kell értenie azt is, hogy a kutatói értelmezés hogyan formálta át ezeket az értelmezéseket.

Végül, Yardley (2000) utolsó kritériumrendszere a kutatás hatásáról és fontosságáról szól. Ezt pedig szintén alapvetôen az olvasónak kell eldöntenie.

\section{RELIABILITÁS}

Az IPA megbízhatóságának kérdésével Rodham, Fox és Doran (2015) foglalkozik, kiemelve, hogy az IPA-t használó szerzók a kutatás menetét ismertetve gyakran nem említik, hogyan biztosították az elemzés megbízhatóságát. Mivel az IPA-kutatás szabályokat kevéssé követô, kreatív folyamatként jellemezhetô (Smith és mtsai, 2009), ez még inkább szükségessé teszi a megbízhatóság igazolását.

Rodham, Fox és Doran (2015) azt javasolják, hogy a kutatásban részt vevô minden személy hallgassa meg az interjúkról készült hangfelvételeket, majd azokat egy közös elemzési folyamat (shared analysis) során értelmezzék. A szerzók saját kutatásuk elemzési folyamatát hozzák fel példaként, melynek során azt tapasztalták, hogy az a kutató, aki csak az interjúszövegek átiratát olvasta, elôítéletesebben értelmezte az interjúalanyok beszámolóját, mint azok a kutatók, akik az interjút készítették és/vagy a felvéte- 
leket meghallgatták. A hangfelvételek hallgatása és a vizsgálati személy által használt verbális eszközök (hanglejtés, hangsúly, hangerô) is az elemzés tárgyát képzik, ezáltal könnyebb elérni, hogy belehelyezkedve az interjúalany helyzetébe a kutatók megértsék az adott helyzetet, tapasztalatot. Az interjúk meghallgatása után a közös elemzési folyamat következett, melynek során - „túllépve a kezdeti különbségeken” - a fơtémák kialakításában és elnevezésében a „középút” megtalálására, konszenzus létrehozására törekedtek. Az elemzésnek ezt a szakaszát elôsegítette, hogy valamennyien ismerték a hangfelvételeket.

A szerzôk felhívják a figyelmet arra, hogy az IPA reliabilitását biztosító közös elemzési folyamat akkor a leghatékonyabb, ha elfogadó közegben zajlik, ahol a részt vevó kutatók szabadon megoszthatják észrevételeiket a másik kutató interpretációjával kapcsolatban, ekkor felfedezhetôek és „zárójelezhetőek” azok az elôítéletek, melyek befolyásolhatják az elemzést. Továbbá kiemelik, hogy az IPA-elemzés kulcsfontosságú eleme egyrészrôl a reflexivitás - amikor kutató tudatában van annak, hogy ô elkerülhetetlenül a kutatás része, ezért befolyásolhatja azt -, másrészrôl a „kíváncsiság” (curious stance) fenntartása - ekkor a kutató azzal a feltételezéssel vesz részt az elemzésben, hogy a vizsgált jelenséget nem érti, vagy arról nem tud semmit, így megkérdôjelezôdik és zárójelbe helyezhetô az elôzetes tudása. A szerzók saját kutatásuk elemzési tapasztalatában ezek az elemek (mint reflexivitás, kíváncsiság, nyitottság) tették lehetôvé, hogy jól használják azt a duális szerepet, melyet az IPA-kutató a kettôs értelmezés (double-hermeneutic) során vesz fel.

Rodham, Fox és Doran (2015) további javaslata alapján az IPA-publikációk fontos jellemzője a transzparencia, mely lehetőséget ad az olvasónak, hogy megismerje az elemzés folyamatát, és azt, hogy a szerzók hogyan biztosították a kutatás megbízhatóságát.

\section{AZ IPA ALKALMAZÁSA}

\section{A krónikus betegség tapasztalata}

A súlyos vesebetegségben szenvedóknél alkalmazott dialízises kezelés pszichológiai következményeit több kutatás vizsgálta: elsôsorban a társuló depressziót, illetve a külsô-belsố kontroll kérdését (általában a betegeknél külsố kontroll alakul ki, míg a belsô kontroll jobb pozitív eredménnyel társul) (összefoglalóan: Smith, Flowers és Larkin, 2009). Az IPA alkalmazása azért merült fel ennél a betegcsoportnál, mert a szerzók hiányolták a szakirodalomból a dialízis hatásának feltárását a betegek mindennapi életére és a saját magukról alkotott képére (Smith és mtsai, 2009; Smith, 2006-ban megjelent közleménye alapján írták ezt az ismertetést). Az egy esetet bemutató tanulmányukban a 44 éves Carole szerepel, aki az interjú idôpontjában 6. hónapja vett részt dialízisben egy kórházi osztályon. A félig strukturált interjú Carole-nek a dialízis alatti tevékenységeire, illetve a mindennapi életére gyakorolt hatásaira kérdezett rá. Egy fontos „kibontakozó témát” idézünk az elemzésébôl: „a gépezet részévé váltam”. Ez téma kifejezi Carole érzéseit, aki a dialízist a 6 hónapos kezelés elején még pozitívan fogadta, majd egyre inkább identitásvesztést élt át, végül azt érezte, hogy a „gépezet 
részévé vált”. Az interjúvoló nem kérdezett rá Carole identitására vagy én-élményére, azt Carole spontán fogalmazta meg. Bár az is elképzelhetô lenne, hogy a "gép” Carole énjének kiterjesztése, azonban Carole éppen egy ellentétes folyamatot élt át. Ez az identitásvesztés sokkal fontosabb volt számára, mint a fizikai rögzítettség, amit a három órás dialízis jelentett, és ezt a kórházi környezet, az ápolókkal folytatott beszélgetések csak fokozták, amelyek ugyanis arra korlátozódtak, hogy Carole hogyan érzi magát a dialízis idején, megfelelôen múködik-e a „gép”. Carole-nak nem volt lehetôsége más problémáiról beszélni a kórházi személyzettel. Még a „gépezet részének lenni” is járhatna pozitív érzésekkel - vették számításba a lehetséges interpretációkat a szerzôk -, azonban Carole-nál ez teljes passzivitással és a kiszolgáltatottság érzésével párosult, hiszen a „gép” múködését, teste elhelyezését, a kezelés idôtartamát stb. nem tudta kontrollálni - azt mind a kórházi személyzet végezte. Az interjú során Carole leginkább a dialíziskezelésnek az én-jére kifejtett hatásával foglalkozott, ezt mutatja az az álma is, amelyet az interjú során mesélt el, és amelyet a szerzôk (Smith és mtsai, 2009, 128) párhuzamba állították a dialízisrôl elmondott leírásaival.

A szerzók szerint az álom és a dialízis elbeszélésének hasonlósága miatt a kettô párba állítható: az álom arra utal, hogy Carole hétköznapjait, mindennapos gondolatait mennyire átjárja a dialízis, még álmában sem képes megszabadulni tôle.

A szerzók azonban óvatosságra intenek: egyetlen beteg tapasztalatait nem lehet általánosítani. Pontosabban, a szakirodalmi adatokkal összevetve lehet általánosabb tanulságokat megfogalmazni, mint például a dialízis során a betegnek nagyobb kontroll biztosítása vagy lehetôség szerint az otthoni dialízis minél korábbi bevezetése.

Carole esetének folytatása lehetne például az IPA kiterjesztése több interjúalanyra, vagy Carole útjának követése az otthoni dialízis fázisában, vagy akár azt vizsgálni, hogy Carole észlelt kontrollhiányával kapcsolatban a kórházi személyzet hogyan éli át ezt a helyzetet. Végül a szerzốk Carole álmát összefüggésbe hozzák a hermeneutikai rész-egész megértéssel: az álom jelenti a „részt”, amely Carol esettanulmánya - mint „egész” - alapján válik megérthetôvé, ugyanakkor az esettanulmány sem lenne érthetô és teljes az álom - mint „rész” - nélkül.

1. táblázat. Carole álma és a dialízis párhuzama

\begin{tabular}{|c|c|}
\hline Az álom & A dialízis \\
\hline $\begin{array}{l}\text { „Az ördöggel álmodtam... egy kis szobában } \\
\text { voltam, a mamámmal, összekapaszkodva, } \\
\text { amikor kívülrôl ez a szellem többször a ne- } \\
\text { vemen szólított.” }\end{array}$ & $\begin{array}{l}\text { "Olyasmi, mint várni valamire (nevet), várni } \\
\text { valamire, ami árt nekem és börtönben tart. } \\
\text { Amikor idejössz, azt hiszed, jó helyen vagy, } \\
\text { aztán megmondják, hogy melyik gépet fo- } \\
\text { god kapni." }\end{array}$ \\
\hline $\begin{array}{l}\text { „És aztán hirtelen átrohant a falon (az ör- } \\
\text { dög), utána át a testemen és a másik oldalon } \\
\text { kijött, ideges voltam és olyan volt, mint egy } \\
\text { elektrosokk. Nagyon fájdalmas volt ez a min- } \\
\text { denen átrohanás.” }\end{array}$ & $\begin{array}{l}\text { „Olyan bántó, mert annak (gépnek) a he- } \\
\text { gyestúi, amihez hozzákapcsolnak. A tûkkel } \\
\text { elég fájdalmas és igen, a fém behatolása saját } \\
\text { magad lágy részeibe.” }\end{array}$ \\
\hline $\begin{array}{l}\text { „Aztán halkan újra és újra a nevemen szólí- } \\
\text { tott. Azt gondoltam, hogy biztonságban va- } \\
\text { gyok, és hogy újra szólítani fog, és tudtam, } \\
\text { hogy ez újra elô fog fordulni.” }\end{array}$ & $\begin{array}{l}\text { "Arra gondoltam, Istenem, tudod, ezt újra } \\
\text { érezni fogom, szembe kell néznem ezzel két } \\
\text { nap múlva ismét." }\end{array}$ \\
\hline
\end{tabular}


Szintén dialízises betegekkel végzett vizsgálatot Lindsay, MacGregor és Fry (2014). A hét személlyel felvett interjúk egyik „kibontakozó témája” a dialízis következtében kialakuló testi elváltozások hatása volt, amelyek megjelentek a betegek én-kontroll érzésében, társas és érzelmi kapcsolataiban. A betegség, illetve a dialízis nem csupán önmagában befolyásolta az interjúalanyok életét, hanem a társas kapcsolatokra gyakorolt hatásokon keresztül is: másoktól váltak függôvé, nem tudtak állást vállalni, nem lehetett gyerekük. A szerzók szerint a krónikus betegség folyamatos küzdelmet jelent az interszubjektivitás terében. Három ilyen területet emeltek ki: az elsố a kontrollra törekvés, illetve a kontroll elvesztése. Itt elsôsorban a testi változások fölötti kontrollt igyekeztek az értelmezésbe bevonni, amely azonban az esetek jelentôs részében nem volt lehetséges, mert éppen hogy ezek estek kívül a betegek által uralható tartományon. A testi változások és a szociális környezet közötti kapcsolat volt a második terület, míg a társas kapcsolatokban folytatott „dialógus” a harmadik interszubjektív terület. A „dialógus” a kontrollért folytatott küzdelem egyik formája, amelyet a betegek szúkebb és tágabb környezetük tagjaival folytattak. A szerzók megállapításai szerint a krónikus betegség nem egy konstans állapot, hanem egy folyamatos, soha véget nem érô „egyezkedési sorozat”, ahol az én és a „másik” közötti határ, illetve az én-kontroll (az én gondozása) fölött állandó egyezkedés zajlik. Ebben a folyamatban idôrôl idôre elófordultak olyan állapotok, ahol az alanyok nem tudtak elég kontrollhoz jutni, és bekövetkezett a teljes reménytelenség. A szerzók konklúziója szerint a dialíziskezelést kapó krónikus vesebetegek nem pusztán „betegek”, hanem olyan személyek, akiknek az élete sokszor teljesen megváltozik a betegség következtében, és akik állandó küzdelmet vívnak azért, hogy életük értelmes legyen. Az IPA jelentôsége, hogy rá tud mutatni e küzdelem olyan idiografikus elemeire, amelyek mások számára érthetôvé és átélhetôvé teszik ezeknek az embereknek az életét. Ezáltal a kórházi személyzet is jobban felkészíthetố a velük folytatott kommunikációra.

Az IPA-t több krónikus betegség esetén is alkalmazták: akár a betegek élményeinek, megküzdési módjainak tanulmányozására, akár a betegek és gondozóik együttes (vagy különbözô) élményeinek a vizsgálatára (Smith és mtsai, 2009). Az IPA a jelenlegi tudásunkhoz képest új, „provokatív” nézôpontok megjelenítésére is alkalmas, amit késôbb más vizsgálatokkal tesztelhetünk. Boland, Levack, Hudson és Bell (2012) olyan párokat vizsgált, ahol a pár egyik tagja multiplex szklerózisban szenvedett. A párok megküzdési stratégiájának vizsgálata során - ami IPA interjúval történt - a kutatók azt tapasztalták, hogy az érzelem-fókuszú megküzdések (elkerülés, ábrándozás) hatékonyabbak a probléma-fókuszúaknál. Például az elkerülô megküzdés megmutatkozott abban, hogy a párok nem alakítottak ki hosszú távú terveket, amik feltehetôn rosszabb állapottal számoltak volna, mint a jelen állapot. A kutatásban részt vevôk elfogadták a betegség jelenlétét, azonban igyekeztek elkerülni a „legrosszabb forgatókönyv” tervezését, illetve ilyen jövôkép kialakítását - ami viszont a probléma-fókuszú megküzdéshez szükséges lett volna. A szerzoók szerint az elkerülő típusú megküzdésnek szerepe lehet a hatékony megküzdésben, azonban hogy pontosan milyen mértékben, illetve a betegség progressziójának melyik fázisában, az már esetenként változhat, illetve további kutatásokat tesz szükségessé. Ezzel összhangban vannak Toombs kutatásai (Toombs, 1993), aki maga is SM-mel él, és fenomenológiai szemléletû kutatásában beszámol arról, hogy milyen romboló, ahogyan a progresszív, 
gyógyíthatatlan kórképeknél az egyének idôhöz való viszonya átalakul. Például megjelenik a „ha, akkor” idôiség („ha megérem a jövô hónapot, ha jók lesznek az eredményeim”) vagy a negatív jövôvárás, amelynek során már a jelenben együtt élnek a progrediáló kórkép várható jövôjével.

\section{Pszichoaktív anyag használat - függöség - felépülés}

Shinebourne és Smith (2009) a túlzott alkoholfogyasztás és a részegség hatását mutatja be Alison példáján. Alison 31 éves, egyedülálló nő, aki az interjú idôpontjában egy alkoholproblémákkal foglalkozó nappali ellátást vett igénybe 8 hónapja. Ebben a publikációban a szerzók csak az alkohol hatásával foglalkoznak (a felépüléssel nem). Alison példája nemcsak az alkohol hatása és a részegség bemutatása miatt érdekes, hanem az IPA-elemzés szempontjából is: példa arra, ahogy a szerzôk az elemzés elôrehaladtával egyre jobban kibontják Alison problémás alkoholfogyasztását és annak gyermekkori elôzményeit. Az elsố „kibontakozó téma” a „szelf mint részeg” észlelése. Az alkoholivás Alison számára egy olyan állapotot eredményezett, amelyben megjelent a mozgás, az oszcilláció és az instabilitás. Egy metaforával összegezte ezt az érzést: ilyenkor úgy érezte magát, mintha a tengerben lebegne, a hullámok ringatnák, nem éri el a lába a talajt, mert egy hullám újra elkapja. A metafora a stabilitást és a biztonságot is tartalmazza: a talaj, a tengerpart, a strand megjelenítésével. A víz kockázatos, mert el lehet merülni benne, ugyanakkor a lehetôségek horizontját is megmutatja: mit hoz a következô hullám? Alison számára a részegség egy lehetôség, út a rosszkedvbôl és a depresszióból az élvezet, az elégedettség és a szociabilitás felé. Ugyanakkor a részegség veszteségek sora is: a kontroll, a tudat, a memória elvesztéséé; együtt jár azzal, hogy „beteg” (másnapos) lesz, zavart, úgy érzi, hogy károsítja az agyát. A részegség pozitív és negatív hatásai - mint egy spirál - követik egymást, és a spirál mozgása soha nem áll le.

Az elemzés következó témája az „egy szerepet alkottam magamnak”: azaz, ez a téma mutatja meg, hogy Alison hogyan tudja az alkohol és a részegség okozta kettôsséget és ambivalenciát kezelni. A részegség okozta megváltozott tudatállapotot a „táncosnô” karakterrel jellemzi, amellyel szemben áll a „normál” (józan) állapota. A két én közötti feszültséget mutatja, hogy Alison megpróbált kevesebbet inni, de úgy érezte, hogy barátai elvárják tôle, hogy vicces és izgalmas „táncosnô” legyen. Ô maga is érezte néha, hogy szeretné jobban megismerni ezt a „táncosnôt”, akit elô tud hívni, ha iszik, de csakis akkor. Megpróbált más módon is közel kerülni hozzá, a felszínre hozni, de nem sikerült. Néha nem is tudta eldönteni, hogy ez a karakter ténylegesen létezik-e a testében (a „táncosnôt” a testébe lokalizálta). A téma explorációja során kiderült, hogy Alison - testvéreivel együtt - gyermekkorában táncolt. Szigorú nevelési elveket valló családban nôttek fel, ahol a tánc volt az egyetlen önmegvalósítási lehetôség. Alison úgy érezte, hogy az ivással ezt az elnyomott, gyermekkori karaktert kelti életre. Az interjúban a szerzók a továbbiakban azzal foglalkoztak, hogy ezeket az egymással konfliktusban álló én-részeket Alison hogyan tudja integrálni. Ez volt a harmadik, utolsó téma: a „szelf percepciója”. Alison ezt ismét egy metaforával érzékeltette: néha olyannak érzi magát, mint a víz: sodorja az ár, „folyékonynak” érzi magát. Máskor viszont olyan, mint a túz: szenvedélyes, impulzív és gyerekes. Alison egyik „része” számára 
az alkohol méreg; az ivást búntudat övezi, míg a másik „része” számára önsorsrontó folyamat, amely ugyanakkor a megtisztulás felé is utat nyit. Az alkoholfogyasztásnál megjelent annak kontrolljára való törekvés is, mint egy folyamatos küzdelem: a „filmszakadástól" (memóriazavartól) való ijedelem küzdött az alkohol kreatív, energetizáló és élvezetes hatásaival. Alison érzelmeinek „egy része” megtisztulni akart az alkoholtól, míg másik „része” élvezte az iváshoz kapcsolódó káoszt és mélységeket.

Larkin és Griffiths (2002) addikciókkal kapcsolatos vizsgálatukban addikt személyek terápiás központjában készített terepjegyzókönyveket és beszélgetésekrôl készített jegyzôkönyveket vetett alá az IPA-nak. A függôséggel kapcsolatban csak néhány „fötémájukat” ismertetjük.

$\mathrm{Az}$ addikt személyek sokszor ûrt éreztek magukban: identitásuk vagy önismeretük „hiányát”, amit az addikcióval „töltöttek be”, és „alkoholistákká”, ,játékosokká” váltak. Ebben az értelemben számukra az addikció nem egy „menekülő” viselkedés volt, hanem éppen ellenkezóleg, egy kísérlet saját tapasztalataik megragadására, a tapasztalatok fölötti kontroll megszerzésére. Ezek a problémás viselkedések a terápiás központ csoportos megbeszélésein váltak problémássá, amikor kiderült, hogy ezeket bizonyos negatív érzelmi állapotoktól (magány, bûntudat, szégyen) történô megszabadulásra használták. A kliensek különbséget tettek az „addiktív” és a „normál” viselkedéseik között, továbbá az „addiktív” viselkedés egészét addiktívnak tartották, azaz már maga a viselkedés volt addiktív és nem csupán a viselkedés elófordulásának mennyisége. Például a negatív érzelmi állapotoktól való megszabadulásra használt viselkedés önmagában „addiktívnek” minôsült (függetlenül attól, milyen gyakran jelent meg ez a viselkedés). Ugyanakkor ezek az „addiktív” viselkedések egyre inkább eltávolították a klienseket a vágyott társas kapcsolataiktól, így egyre inkább magányosabbá váltak, a következményes negatív érzésekkel, amelyek újabb addiktív magatartást váltottak ki, kialakítva egy addiktív ciklust. Az elôzôekben említett Alison esetéhez hasonlóan (Shinebourne és Smith, 2009) az ebben a kutatásban szereplő addikt személyek is kettôs identitásról, illetve én-élményrôl számoltak be: az „addikt” és a „normál” énrôl. Alison esetével szemben, úgy érezték azonban, hogy az „addikt” énjük bármikor a felszínre törhet, ezért folytonos aggodalommal tekintettek mindennapi rutinjukra. Itt meg kell jegyezni, hogy Larkin és Griffiths (2002) esetében csoportos terápiás helyzetben is készültek feljegyzések, tehát a terápiás elvárások jelentôsen befolyásolták azt, amit az „addikt” énjük múködésérôl a kliensek elmondtak.

Hill és Leeming (2014) kutatásában a Névtelen Alkoholisták (AA, Alcoholics Anonymous) 12 lépéses programjában lévô, abban már elôrehaladást mutató alkoholisták vettek részt: az „elôrehaladás” Larkin és Griffiths (2002) résztvevôihez viszonyítva értendô. Ugyan az interjúalanyok már döntöttek a felépülés mellett, elhagyták az ivást, de a korábbi alkoholista identitásuk - és az azzal járó stigma - még a felépülésük során is folyamatos munkát kívánt tôlük, hogy megküzdjenek a korábbi énképükkel és stigmájukkal. Az AA egy narratívát kínál a felépülésre, amelyben az alkoholista identitást, illetve stigmát is kezelik, de ezt a narratívát az interjúalanyok nem pusztán átvették, hanem egy folytonos munkában, fogalmazhatunk így:„magukra igazítják”. Az AA szerint ugyanis a felépülő, absztinens tag is „alkoholista” - csak éppen felépülő alkoholista. Azaz, nem tagadja ezt az identitást, illetve a vele járó stigmát, hanem pozitív módon átértelmezi. Azonban ez az átértelmezés nem egyszeri aktus a Hill és Leeming 
(2014) kutatásában szerepló személyeknek, hanem folyamatos újra és újra értelmezést kívánó munka. Az IPA erôssége ilyen esetekben ennek a folyamatosan értelmezô és jelentésadó munkának a feltárása és részletes bemutatása.

Shinebourne és Smith (2011) kutatásában már legalább 15 éve felépülô nôk szerepeltek. Náluk már nem az alkoholista identitással vagy a stigmával történô megküzdés jelentette a legnagyobb problémát. Ők már beépítették az életükbe az AA tanítását (a 12 lépést); az érdekes tehát éppen az volt, hogy ez hogyan történt. Megint azt látjuk, hogy az IPA segítségével a mindennapos rutinok válnak láthatóvá és értelmezhetôvé, a módszer tehát képes feltárni a szubjektív tapasztalat komplex rétegeit. Ilyen volt ebben az esetben az interjúalanyok „öngondoskodása”, amit nap mint nap elvégeztek. Shinebourne és Smith (2011) ezt az öngondoskodást a foucault-i öngondoskodással (technologies of the self) állítják párhuzamba. Foucault-nál (2001) ez olyan tevékenységeket jelent, amit az egyén annak érdekében végez, hogy önmagát „átalakítsa”, és „boldog, tiszta, bölcs, tökéletes vagy halhatatlan” legyen. Foucault szerint ezt a tevékenységet az egész életen át végezni kell, és magában foglalja az egyén önmaga vizsgálatát, monitorozását. Ebben az önismereti munkában, gyakorlatok révén egy etikus személyiség tud kialakulni, aki tisztában van azzal, hogy ki ô, mit tesz, és mire lenne képes. Az „etikus személy” Foucault szerint (és ebben az értelemben az AA számára is), mindig mások társaságában, másokkal együtt alakul ki és marad fenn. Shinebourne és Smith (2011) arra is felhívja a figyelmet, hogy bár az interjúalanyaik hosszú ideje elkötelezôdtek a nem ivás mellett, mégis egyfajta veszteségként élték meg ivós korszakuk maguk mögött hagyását (elvesztették azt a „másságot”, amit az ivás adott nekik), bár a felépülés „nyeresége” ezt a veszteséget messze meghaladta. Itt megint egy olyan jelenséget látunk, ahol az IPA előnye megjelenhet: a domináns narratíva „mögött” levő, az egyén számára az adott énképpel vagy identitással nem összeilleszthetô tartalmak megjelenítése és értelmezése.

Vangeli és West (2012) dohányosok nemdohányzó identitásának vizsgálatát is érdemes megemlíteni. A 10 fôvel folytatott kutatásban az interjúalanyok leszokásban levô dohányosok voltak. A vizsgálat fókuszában az interjúalanyok identitásváltozása állt: mit jelent dohányosból nemdohányossá válni. Az interjúkból kiderült, hogy ez az identitásváltozás feltétlenül szükséges volt a dohányzás abbahagyásához. Az identitásváltozást elôsegítette a csoportban leszokó dohányosok esetében a „csoportos leálló” átmeneti identitása is, ami a csoportos leszokás támogató program során alakult ki. A kutatók szerint a „nemdohányzó” identitás egy felületes szinten jelentkezett, ahol az interjúalanyok problémamentesen, sôt, büszkén vallották magukat nemdohányzónak (öncímkézés). Ugyanakkor egy mélyebb szinten a dohányzás továbbra is vonzó maradt a számukra: így a teljes nemdohányos identitásuk nem alakulhatott ki. A szerzók el is különítik a „volt-dohányos” identitást, ahol a dohányzás vonzása erôs, és a már ettôl a vonzódástól megszabadult „nemdohányos” identitást, ami az elôzô „fluiditásával” szemben már tartósnak mondható. Ennek a megkülönböztetésnek az intervenció irányára is hatása van: célszerúbb elôször a „volt-dohányos” identitásváltozást elősegíteni, majd egy következô lépésben a „nemdohányos” identitást, különösen olyan személyeknél, akik évtizedeken keresztül dohányoztak.

Saját vizsgálatunkban drogrehabilitációs intézményben dolgozó tapasztalati szakértôket (azaz, felépülô függôket, akik segítôként dolgoztak) vizsgáltunk. A hat interjú- 
alanyt két intézménybôl választottuk ki. A szerhasználat, majd a felépülés élménye, illetve a segítô munka tapasztalatai álltak az interjúk középpontjában (Kassai és mtsai, 2015; Pintér, Kassai és Rácz, 2015; Rácz és mtsai, 2015). Jelen témánk szempontjából kiemeljük az interjúalanyok szerhasználati élményét. Itt olyan megfogalmazások szerepeltek, ahol a szerhasználat vagy a ,játék” olyan folyamatként jelent meg, mely kezdetben „izgalmas”, „különleges” volt, késôbb azonban „ördögi körré” „tehetetlenséggé” változott.

A retrospektív jellemzések gyakran számolnak be arról, hogy másnak akarták mutatni magukat, amiben a szerhasználat volt a segítségükre: „...féloós egér voltam, kivül persze mutatnom kellett azt, hogy megállom a helyem, hogy vagány vagyok” (Zénó); „egy üzött vad voltam az ôrület határán” (Feri); "felpörgetett”, „erôt adott” egyfajta „segédeszköz” volt, „amivel együtt tudtam müködni a világgal” (Zsolt), „önhittség” „önszerelem”, „önsajnálat” „önmagamtól akartam szabadulni” (Balázs). Ezek a megjegyzések többnyire arra utaltak, hogy a szerhasználat vagy a játékszenvedély „kifelé”, a többi ember felé mit mutatott meg a személyiségükból. Ezzel szemben jelenik meg sok interjúalanynál az, hogy „belül”, „valójában” milyenek is voltak: „depressziós”, „bizonytalan”, „fals érzelmekkel” bíró, „félelemmel” teli.

Ezeket a megfogalmazásokat érdemes összevetni a segítés élményeként megfogalmazott tapasztalatokkal. A segítés személyes jelentése két részre osztható. Az egyik a segítôre vonatkozik: a közös függôség miatt jobban hallgatnak rá, elfogadják, a segítôk ezt az énjük kiteljesedéseként, fejlơdésként jellemezték. A segítés másik jelentése a kliensrôl szól, azaz, hogy a segítô hogyan tud jelen lenni a kliens számára. Itt olyan kifejezések jelentek meg, mint a „kísérés”, „tükör”, az „egyenrangú fél”, a „biztos pont”, a „sorsközösség vállalása”, a „mentor”, valamint megjelentek a segítés metaforái.

„Szóval bennem vagy pár jó kép ezzel kapcsolatban, mikor a vándor megy az úton, és az egész utat nézve nem is, nem tudom, hogy ô honnan és hová megy, de van egy bizonyos szakasza az életének, amikor kisérốre van szüksége. Kicsit olyan, mit amikor-egy másik képpel élve - egy fiatal facsemetét elültetünk, és akkor leverünk mellé egy karót, és az a karó nagyon szükséges, mert jön a szél, a vihar, jönnek, a nem tudom fiatalok, és ki akarják szakítani, tépni onnan, megrángatják, de ottmarad a karó, és az segít neki. De van egy pillanat, amikor a fa túlnố a karón, és már vastagabb a fatörzse, mint maga a karó, akkor pedig ki kell onnan venni” (Zénó).

A beszámolókban rendre megjelenik az a tapasztalat, hogy segítô nem irányít vagy „megment”, hanem csak a kliens lehet képes a változásra. A következó idézetek ezt mutatják: „Csak várok, amíg elmennek a forráshoz. Nem is vezetem óket a forráshoz, hanem fogom a vállukat” (Balázs). A következô két idézet is tárja fel: a segítés „semmiképp nem egy ilyen megmentố szerep, semmiképp nem a felelösség átvállalása” (Zénó), „nem én vagyok a megmentôjük" (Balázs). A segítés élményének leírásában gyakran tapasztaltuk azt, hogy azokat a jellemzóket hangsúlyozzák, amiket a szerhasználatuk alatt hiánynak éltek meg. A felépüléssel az a kettôsség, amit a szerhasználat alatt az énjükre jellemzônek véltek - kifelé egy „hamis” kép, belül az „igazi én” -, megváltozott. A „felépüló énjük” kialakulásával megszûnt ugyanis a kettôsség. A tapasztalati segítook esetében a „felépülő én” kialakulása egy ponton együtt járt a „segító énjük” kifejlôdésével (Kassai és mtsai, 2015; Rácz és mtsai, 2015). Az IPA-módszer árnyaltan képes bemutatni a tapasztalati segítôk felépülését, majd pedig a segítô én kialakulását és a segítés mikrofolyamatait (Kassai és mtsai, 2015; Rácz és mtsai, 2015). 


\section{ÖSSZEGZÉS}

Az IPA módszere jól alkalmazható olyan kvalitatív pszichológiai kutatásokban, ahol egy-egy pszichológiai jelenséget kisszámú résztvevố részletes értelmezési munkájával igyekszünk bemutatni. A módszer előnye éppen a részletgazdagságban, illetve az olvasó értelmezô munkáját és empátiás azonosulását lehetôvé tevô idiografikus megközelítésében rejlik. Ezt saját kutatásunkban is tapasztaltuk (Kassai, Pintér \& Rácz, 2015). A módszer korlátai közé tartozik, hogy az eredmények a kis létszámú és speciálisan megválasztott minta miatt nem általánosíthatók (azonban ez a kvalitatív kutatásokra általában is igaz). Másik - ismeretelméleti - korlátja, hogy intenzíven épít a kutató értelmezési folyamataira (ahogy az interjúalanyok értelmezéseit egy második szinten értelmezi), amelyeknek azonban nincsenek egyértelmú, objektív indikátorai vagy kritériumai.

\section{IRODALOM}

Boland, P. Levack, W. M. M., Hudson, S., \& Bell, E. M. (2012). Coping with multiple sclerosis as a couple: 'peaks and troughs' - an interpretative phenomenological exploration. Disability E Rehabilitation, 34(16), 1367-1375.

Benner, P. (1984). From novice to expert: Excellence and power in clinical nursing practice. Menlo Park: Addison-Wesley.

Benner, P. (Ed.), (1994). Interpretive phenomenology: Embodiment, caring, and ethics in health and illness. Thousand Oaks, CA: SAGE.

Blumer, H. (2000). A társadalom, mint szimbolikus interakció. In Felkai G., Némedi D., \& Somlai P. (szerk), Olvasókönyv a szociológia történetéhez II. Szociológiai irányzatok a XX. században (p. 323). Budapest: Új Mandátum.

Benner, P., \& Chan, G. K. (2010). Introduction. In G. K. Chan, K. A. Brykczynski, R. E. Malone, \& P. Benner (Eds.), Interpretive phenomenology in health care research (pp. 19-25). Indianapolis, IN: Sigma Theta Tau International.

Charmaz, K. (2013). Lehorgonyzott elmélet. In P. Bodor (szerk.), Szavak, képek, jelentés. Kvalitatív kutatási olvasókönyv (pp. 61-94). Budapest: L’Harmattan.

Charmaz, K., \& Henwood, K. (2008). Grounded Theory. In C. Willig, \& W. Stainton-Rogers (Eds.), The SAGE handbook of qualitative research in psychology (pp. 240-259). London: SAGE.

Corbin, J., \& Strauss, A. (2015). A kvalitatív kutatás alapjai. A Grounded Theory elemzési módszer technikája és eljárásai. Budapest: L'Harmattan.

Crowther, S., Smythe, E., \& Spence, D. (2014). The joy at birth: An interpretive hermeneutic literature review. Midwifery, 30, 157-165.

Eatough, V., \& Smith, J. A. (2008). Interpretative phenomenological analysis. In C. Willig, \& W. Stainton-Rogers (Eds.), The SAGE handbook of qualitative research in psychology (pp. 179-194). London: SAGE.

Fehér, I. M. (2007). Elôszó. In M. Heidegger, Lét és idô. Budapest: Osiris.

Foucault, M. (2000). Elmebetegség és pszichológia. A klinikai orvoslás születése. Budapest: Corvina.

Foucault, M. (2001). A szexualitás története III. Törôdés önmagunkkal. Budapest: Atlantisz Könyvkiadó.

Gadamer, H. G. (1960/2003). Igazság és módszer. Egy filozófiai hermeneutika vázlata. Budapest: Osiris.

Gelencsér, K. (2003). Grounded Theory. Szociológiai Szemle, 43(1), 17-30. 
Giorgi, A. P., \& Giorgi, B. (2008). Phenomenological psychology. In C. Willig, \& W. StaintonRogers (Eds.), The SAGE handbook of qualitative research in psychology (pp. 165-178). London: SAGE.

Heidegger, M. (1927/2007). Lét és idô. Budapest: Osiris.

Hill, J. V., \& Leeming, D. (2014). Reconstructing 'the Alcoholic': recovering from alcohol addiction and the stigma this entails. International Journal of Mental Health and Addiction, 12(6), $759-771$.

Husserl, E. (1905/2002). Elôadások az idốról. Budapest: Atlantisz.

Husserl, E. (1911/1972). A filozófia, mint szigorú tudomány. In E. Husserl: Edmund Husserl válogatott tanulmányai (pp. 111-192). Budapest: Gondolat.

Husserl, E. (1936/1998). Az európai tudományok válsága I-II. Budapest: Atlantisz.

Kassai, Sz., Pintér, J. N., \& Rácz, J. (2015). Addiktológiai területen dolgozó tapasztalati szakértôk: interpretatív fenomenológiai analízisen alapuló kutatás. Psychiatria Hungarica, 30(4), 372-388.

Kesselring, A., Chesla, C., \& Leonard, V. (2010). Why Study Caring Practices? In G. K. Chan, K. A. Brykczynski, R. E. Malone, \& P. Benner (Eds.), Interpretive phenomenology in health care research (pp. 3-22). Indianapolis, IN: Sigma Theta Tau International.

Langdridge, D. (2007). Phenomenological Psychology. Theory, Research and Method. London: Pearsons.

Larkin, M., \& Griffiths, M. D. (2002). Experience of addiction and recovery: the case for subjective accounts. Addiction Research and Theory, 10(3), 281-311.

Lindsay. H., MacGregor, C., \& Fry, M. (2014). The experience of living with chronic illness for the haemodialysis patient: An interpretative phenomenological analysis. Health Sociology Review, 23(3), 232-241.

McNiesh, S. (2010). A Fusion of Horizons: Meaning and Understanding in Becoming a Nurse. In G. K. Chan, K. A. Brykczynski, R. E. Malone, \& P. Benner (Eds.), Interpretive phenomenology in health care research (pp. 23-40). Indianapolis, IN: Sigma Theta Tau International.

Mead, G. H. (1934). Mind, self and society. Chicago, IL: University of Chicago Press.

Merleau-Ponty, M. (1945/2014). Az észlelés fenomenológiája. Budapest: L’Harmattan.

Merleau-Ponty, M. (1964/2007). A látható és a láthatatlan. Budapest: L'Harmattan.

Merleau-Ponty, M. (1998). A közvetett nyelv és csend hangjai. In Bacsó B. (szerk.), Kép, fenomén, valóság (pp. 142-178). Budapest: Kijárat.

Mitev, A. Z. (2012): Grounded theory, a kvalitatív kutatás klasszikus mérföldköve. Vezetéstudomány, 43(1), 17-30.

Osborn, M., \& Smith, J. A. (1998). A personal experience of chronic being lower back pain: An interpretative phenomenological analysis. British Journal of Health Psychology, 3, 65-83.

Pintér, J. N., Kassai, Sz., \& Rácz, J. (2015). A sajátélmény szerepe a professzionális és a tapasztalati segítôvé válásban. A felépülố identitás bemutatása interpretatív fenomenológiai analízissel. In Csabai M., \& Papp-Zipernovszky O. (szerk.), Gyógyítók egészsége. A hivatás kihívásai és a változás lehetôsége (pp. 85-105). Budapest: Oriold és Társai Kiadó.

Rácz, J., Kassai, Sz., Pintér, J. N., Benedeczki, P., Dobó-Nagy, Z., Horváth, Zs., \& Gyarmathy, V. A. (2015). The Therapeutic Journeys of Recovering Helpers - an Interpretative Phenomenological Analysis. International Journal of Mental Health and Addiction, 13(6), 751-757.

Ricoeur, P. (1990). Soi-même comme un autre. Paris: Seuil.

Rodham, K., Fox, F., \& Doran, N. (2015). Exploring analytical trustworthiness and the process of reaching consensus in Interpretative Phenomenological Analysis: Lost in Transcription. International Journal of Social Research Methodology, 18(1), 59-71.

Ryan, G. W. \& Bernard, H. R. (2000). Data management and analysis methods. In N. K. Denzin, \& Y. S. Lincoln (Eds.), Hand book of qualitative research (pp. 769-802). London: Sage. 
Shinebourne, P., \& Smith, J. A. (2009). Alcohol and the self: An interpretative phenomenological analysis of the experience of addiction and its impaction the sense of self and identity. Addiction Research and Theory, 17(2), 152-167.

Shinebourne, P., \& Smith, J. A. (2011). 'It is just habitual': An Interpretative Phenomenological Analysis of the experience of long-term recovery from addiction. International Journal of Mental Health and Addiction, 9, 282-295.

Shinebourne, P. (2011). The theoretical underpinnings of Interpretative Phenomenological Analysis (IPA). Existential Analysis, 22(1), 16-31.

Silverman, D. (2013). Doing qualitative research. London: Sage.

Smith, J. A. (1996). Beyond the divide between cognition and discourse: Using interpretative phenomenological analysis in health psychology. Psychology $\mathcal{E}$ Health, 11, 261-271.

Smith, J. A., \& Osborn, M. (2007). Interpretative phenomenological analysis. In J. A. Smith (Ed.), Qualitative Psychology (pp. 53-80). London: SAGE.

Smith, J. A. (2011). Evaluating the contribution of Interpretative Phenomenoligical Analysis. Health Psychology Review, 5(1), 9-27.

Smith, J. A., Flowers, P., \& Larkin, M. (2009). Interpretative phenomenological analysis: Theory, method and research. London: Sage.

Toombs, S. K. (1993). The Meaning of Illness: A Phenomenological Account of the Different Perspective of Physican and Patient. Norwell, Mass: Kluwer.

Ullman, T. \& Olay, Cs. (2011). A kontinentális filozófia a XX. században. Budapest: L’Harmattan.

Vangeli, E., \& West, R. (2012). Transition towards a 'non-smoker' identity following smoking cessation: An interpretative phenomenological analysis. British Journal of Health Psychology, 17, 171-184.

Wagstaff, C., \& Williams, B. (2014). Specific design features of an interpretative phenomenological analysis study. Nurse Researcher, 21(3), 8-12.

Willig, C. \& Stainton-Rogers, W. (2013). The SAGE handbook of qualitative research in psychology. London: Sage.

Yardley, L. (2000). Dilemmas in qualitative health research. Psychology and Health, 15, 215-228.

Wertz, F. J., Charmaz, K., McMullen, L. M., Josselson, R., Anderson, R., McSpadden, E. (2011). Five ways of doing qualitative analysis. New York: The Guilford Press.

\title{
INTRODUCTION OF THE INTERPRETATIVE PHENOMENOLOGICAL ANALYSIS (IPA) AS A QUALITATIVE RESEARCH METHOD
}

\section{LITERATURE REVIEW}

\author{
RÁCZ, JÓZSEF - KASSAI, SZILVIA - PINTÉR, JUDIT NÓRA
}

Based on a literature review authors have presented the Interpretative Phenomenological Analysis (IPA). The method is applied in qualitative psychological studies. In this review phenomenological and hermeneutic basics of IPA are summarized. Idiographic application of IPA is highlighted; this is one of the advantages of the IPA: it makes possible very detailed analysis with small, homogenous samples. Methodological differences with other phenomenological approaches are also discussed. Then, the application of the IPA is presented: the study question, the sample selection, the interview making, steps of the phenomenological interpretation of the transcripts of the interviews. The question of validity is also presented as a limitation of the IPA: small sample size and the epistemological limitations: there are no objective criteria of interpreta- 
tions. Finally, some IPA studies are shown regarding the applicability of the method in qualitative psychological researches. For example, the experience of chronic illnesses, the experience of psychoactive substance use, the dependence and the recovery process. In these studies the core question of the IPA are the change of the relationship to the person' self or identity.

Key words: interpretative phenomenological analysis, qualitative psychological study, interview analysis, identity 